\title{
Proactive Personality, Career Success, dan Career Adaptability pada Karyawan PT Kereta Api Indonesia Daop 8 Surabaya
}

\author{
Tri Siwi Agustina \& Ivan Rizky Muhammad \\ Departemen Manajemen, Fakultas Ekonomi dan Bisnis, Universitas Airlangga \\ e-mail: agustina2772@gmail.com, ivanrizkymuhammad@gmail.com
}

\begin{abstract}
Proactive personality is an important factor in a boundaryless career. The reason is, in the boundaryless career period, the work environment becomes uncertain and the challenges in a career are increasingly complex. Therefore, there is a need for an adaptive attitude in running a career. Proactive personality is seen as a form of career adaptability. This study analyzes the relationship between proactive personality, career adaptability and career success (subjective and objective). Samples from this study are 41 people from employees of PT KAI DAOP 8 Surabaya which is included in the State-Owned Enterprises (BUMN). The respondents' data were analyzed using Partial Least Square (PLS) using the SmartPLS 3.0 program. The results of this study indicate that when proactive personalities increase, career adaptability and subjective career success will increase too. While the other results of this study are when proactive personality increases, it does not significantly influence objective career success. Similarly, increasing career adaptability does not significantly influence objective career success.
\end{abstract}

Keywords: personality, proactive personality, career, career adaptability, career success, subjective career success, objective career success

\section{A. LATAR BELAKANG}

Seseorang yang memutuskan untuk memulai bekerja, baik itu bekerja di perusahaan maupun membuka usaha bisnis sendiri tentunya memiliki suatu tujuan yang ingin segera dipenuhi, mulai dari jangka pendek hingga jangka panjang. Selain itu, seseorang tentunya memiliki harapan-harapan yang ingin dicapai selama bekerja, khususnya ketika seseorang bekerja di dalam suatu perusahaan. Bekerja merupakan salah satu upaya individu untuk memperoleh peningkatan kelayakan kehidupan yang lebih baik di mana posisi atau jabatan dalam perusahaan merupakan salah satu faktor yang berpengaruh terhadap hal tersebut. Seorang pegawai tentunya cenderung akan mempunyai keinSantosn untuk naik ke jabatan yang lebih tinggi dari sebelumnya, karena diharapkan akan membawa kepada suatu kondisi yang lebih baik bagi kehidupannya. Hal ini berkaitan erat dengan bagaimana seseorang mengembangkan kariernya. Pola karier yang telah menjadi semakin beragam, tanpa batas (boundaryless), dan non-linier memunculkan perdebatan bahwa pengembangan karier yang sukses mengharuskan pekerja untuk mengembangkan kemampuan (abilities) untuk beradaptasi dan mengendalikan pengembangan diri dalam konteks pekerjaan (Jiang, 2016). Keadaan seperti ini merupakan dampak dari sifat organisasi atau perusahaan yang selalu berusaha untuk memiliki kemampuan adaptasi terhadap perubahan lingkungan yang tidak menentu. Lingkungan yang dimaksud adalah lingkungan pekerjaan yang meliputi keadaan dalam perusahaan itu sendiri, tren permintaan konsumen, dan lain-lain. Akibat dari lingkungan pekerjaan tersebut sangat luas dan bukan hanya dipengaruhi oleh internal perusahaan namun juga eksternal perusahaan, maka keadaan ling- 
kungan seperti ini menjadi sangat tidak menentu. Hal inilah yang menyebabkan perusahaan harus memiliki sikap adaptif yang baik. Selain itu, adanya kemungkinan bahwa perusahaan dapat melakukan downsizing maupun outsourcing untuk mengatasi persaingan yang kompleks, memunculkan konsekuensi bahwa pekerja berupaya untuk mempertahankan dan bahkan meningkatkan nilai mereka di perusahaan di mana individu tersebut bekerja serta pada pasar tenaga kerja guna mengantisipasi ketika dirasa perusahaan tersebut tidak lagi layak bagi dirinya untuk membangun karier atau karyawan tersebut melihat adanya peluang yang lebih baik bagi dirinya di perusahaan lain. Oleh sebab itu, dengan semakin berkembangnya zaman, seorang karyawan dituntut untuk dapat menata atau mengembangkan rencana kariernya sendiri di samping bantuan dari perusahaan untuk mencapai kesuksesan karier. Sukses dalam karier sendiri dibagi menjadi dua yaitu subjective career success dan objective career success.

Career success didefinisikan sebagai hasil psikologis, pekerjaan yang positif, atau prestasi pribadi dan profesional yang dikumpulkan seseorang dari pengalaman kerja mereka (Santos, 2016). Career success dibagi menjadi dua yaitu subjective career success dan objective career success (Santos, 2016). Subjective career success bergantung kepada evaluasi individual dan tanggapan afektif terhadap hasil kariernya yang mencakup beberapa arti. Objective career success adalah pandangan eksternal dari karier dan kesuksesan karier didefinisikan oleh tindakan yang dapat diamati seperti gaji dan promosi (Santos, 2016). Dalam beberapa tahun terakhir terdapat beberapa faktor kepribadian yang diketahui dapat memengaruhi objective career success (gaji dan promosi) dan subjective career success (kepuasan karier) (Spurk dkk., 2013). Inisiatif individu untuk terlibat ke dalam aktivitas dan situasi dalam konteks pekerjaan menjadi fokus penelitian mengenai kepribadian dan karier (Spurk dkk., 2013). Dalam beberapa penelitian mengenai karier, individu dipandang pasif dan lunak (mudah menurut), menekankan pengaruh dari situasi pada perilaku manusia (Seibert, 1999). Sedangkan hal ini akan menjadi sesuatu yang kurang menguntungkan bagi sisi karyawan maupun perusahaan pada masa boundaryless career. Di sisi lain individu yang tidak pasif disebut individu yang proaktif, yaitu individu yang dapat dideskripsikan sebagai mereka yang tidak terbatasi oleh tekanan situasi serta mereka yang mampu memengaruhi perubahan lingkungan, dalam hal ini lingkungan kerja mereka (Bateman dan Crant, 1999). Oleh karena itu, jika dilihat secara menyeluruh, individu dengan proactive personality sangat dibutuhkan dalam masa boundaryless career saat ini.

Individu dalam perusahaan industri berperan besar dalam kinerja perusahaan mengingat dalam segala kegiatan di perusahaan selalu membutuhkan campur tangan dari manusia sehingga menuntut karyawan untuk teliti dalam melaksanakannya. Oleh karena itu, diperlukan suatu keputusan yang bijak saat calon pekerja memutuskan untuk melamar kerja dalam suatu jenis perusahaan industri. Hal ini yang sepatutnya dibangun oleh perusahaan-perusahaan yang ada di Indonesia sebagai negara dengan jumlah penduduk yang besar. Tidak dapat dipungkiri bahwa tuntutan perkembangan zaman, mengakibatkan meningkatnya ekspektasi pelayanan oleh perusahaan. Perusahaan-perusahaan di Indonesia sudah sepatutnya sadar bahwa untuk bersaing dengan para kompetitornya, selain mengandalkan teknologi yang terus berkembang diperlukan juga karyawan-karyawan yang dapat ikut andil dalam pembuatan produk-produk maupun pelayanan yang inovatif dan mempunyai daya saing yang tinggi. 
Perusahaan saat ini dituntut untuk tanggap terhadap perubahan-perubahan lingkungan agar dapat bertahan dalam persaingan. Perubahan dalam aspek lingkungan, teknologi, dan ilmu pengetahuan juga pada akhirnya menuntut karyawan menjadi seseorang individu yang proaktif untuk dapat mencapai kesuksesan kariernya. Hal ini juga terlihat dari semakin kompleksnya job requirement yang diberikan oleh perusahaan sehingga sikap kepribadian reaktif yang merupakan lawan dari proactive personality perlu dihindari oleh para calon karyawan. Individu yang tidak dapat beradaptasi terhadap kompleksitas karier umumnya gagal untuk mendapatkan karier yang baik (Zhu dkk, 2013). Oleh karena itu, career adaptability sangat dibutuhkan untuk mencapai kesuksesan karier dalam menanggapi tantangan pasar saat ini. Career adaptability mengacu kepada seperangkat sikap, perilaku, dan kompetensi yang digunakan individu dalam menghadapi perubahan kondisi kerja dan tuntutan, yang terdiri dari empat dimensi: concern (perencanaan), kontrol (pengambilan keputusan, penentuan), rasa ingin tahu (mengeksplorasi), dan kepercayaan diri (pemecahan masalah, percaya diri) (Bocciardi dkk, 2017).

Berbagai perubahan yang terjadi dalam dunia industri merupakan tantangan tersendiri bagi perusahaan, karena ketidakmampuan perusahaan termasuk karyawan di dalamnya untuk beradaptasi merupakan sebuah ancaman yang dapat mengakibatkan tertinggalnya perusahaan oleh kompetitor lainnya. Tentunya hal tersebut juga menjadi salah satu fokus utama PT KAI (DAOP 8) Surabaya. Berdasarkan visi dan misi PT KAI (Daop 8) Surabaya mencerminkan bahwa perusahaan ini membutuhkan karyawan yang proaktif. Visi perusahaan ini adalah "Menjadi penyedia jasa perkeretaapian terbaik yang fokus pada pelayanan pelanggan dan memenuhi harapan stakeholders "sedangkan misi perusahaan ini adalah "menyelenggarakan bisnis perkeretaapian dan bisnis usaha penunjangnya, melalui praktik bisnis dan model organisasi terbaik untuk memberikan nilai tambah yang tinggi bagi stakeholders dan kelestarian lingkungan berdasarkan empat pilar utama: keselamatan, ketepatan waktu, pelayanan, dan kenyamanan" (https:// www.kai.id/corporate/about_kai/). Visi dan misi perusahaan ini benar-benar dijalankan, terlihat dari penghargaan-penghargaan yang telah dicapai oleh PT KAI (Daop 8). Hingga Oktober 2018 tercatat sebanyak 75 penghargaan telah diperoleh. Selain terlihat bahwa PT KAI (DAOP 8) Surabaya sangat menjunjung tinggi kepuasan pelanggan, selaras dengan visi dan misinya, perusahaan ini juga membutuhkan para pekerja proaktif karena tanpa individu-individu dengan tipe proactive personality maka visi dan misi perusahaan maupun penghargaan-penghargaan tersebut akan sulit untuk dicapai.

Oleh karena itu, individu-individu dengan tipe kepribadian reaktif harus diminimalisasi sehingga akan mendorong tercapainya visi dan misi yang telah dibentuk pada masa pendirian perusahaan tersebut. Adanya potensi ancamanancaman seperti di atas dapat diatasi salah satunya adalah dengan melakukan peningkatan pemahaman yang lebih baik dari perusahaan terkait karier karyawan. Hal yang juga akan dibahas dalam penelitian ini adalah analisis mengenai variabel kontemporer karier yang disebut career adaptability (Spurk dkk., 2013) sebagai mediator dalam hubungan proactive personality dan career success. Individu yang adaptif terhadap kariernya akan lebih sukses karena mereka merencanakan karier mereka lebih efektif, mengatasi keadaan yang belum terjadi di masa depan, serta lebih mudah dipekerjakan pada pasar tenaga kerja terkini (Spurk dkk, 2013). Selaras dengan keadaan yang tidak menentu dan berubah-ubah menjadikan pemimpin maupun karyawan perusahaan untuk dapat adaptif terhadap 
lingkungan kerja mereka. Konsep sikap adaptif dalam boundaryless career ini kemudian dikenal dengan istilah career adaptability.

Berdasarkan pemikiran latar belakang di atas maka dalam penelitian ini diberi judul: Pengaruh Proactive Personality (Proactive Personality) terhadap Career Success Dimediasi oleh Career Adaptability (Career Adaptability) pada PT KAI (Daop 8 Surabaya). Dalam penelitian yang dilakukan, diharapkan akan ditemukan berbagai informasi penting yang bermanfaat bagi proses manajemen dalam PT KAI Daop 8 Surabaya, khususnya dalam bidang pengembangan karier karyawan. Selain itu juga diharapkan dapat memberikan masukan bagi para pimpinan PT KAI (Daop 8 Surabaya) terkait karier karyawan mereka.

\section{B. LANDASAN TEORI}

\section{Proactive Personality}

Proactive personality didefinisikan sebagai kecenderungan yang relatif stabil untuk memengaruhi perubahan lingkungan (Bateman \& Crant, 1993). Proactive personality juga dapat dikaitkan sebagai seseorang yang memiliki sikap relatif tidak terbatasi oleh kekuatan situasional serta seseorang yang dapat memengaruhi perubahan lingkungan (Bateman \& Crant, 1993). Sedangkan Crant (2000) menjelaskan proactive personality berhubungan dengan seseorang yang mengambil inisiatif untuk memperbaiki keadaan saat ini atau menciptakan sesuatu yang baru di mana hal tersebut berarti menantang keadaan status quo dibandingkan secara pasif beradaptasi dengan kondisi saat ini.

\section{Career Success}

Rasdi dkk. (2011) mendefinisikan career success sebagai psikologikal positif atau hasil dari suatu pekerjaan (work-related outcomes) atau pencapaian personal dan pencapaian profesional yang didapat seseorang dari pengalamannya selama bekerja. Hal ini diperjelas melalui pendapat Zhu dkk. (2013) yaitu karier didefinisikan sebagai suatu seri pendek (seperti 3-5 tahun) dari siklus pembelajaran yang memerlukan kemampuan beradaptasi terhadap situasi yang baru melalui eksplorasi, aktivitas percobaan dan penguasaan.

Dilihat dari cara mengukurnya, career success sendiri dibedakan menjadi dua, yaitu subjektif career success dan objektif career success. Istilah objective career success mengacu kepada prestasi karier yang dapat diamati seperti gaji dan sejarah promosi (Seibert dkk., 1999). Sedangkan subjective career success merefleksikan perasaan seseorang atas kepuasan dan prestasi yang dicapai dalam karier mereka (Scott dkk., 1999). Jika ditinjau lebih jauh, dapat ditarik kesimpulan bahwa karyawan atau individu dengan proactive personality tidak hanya memengaruhi kondisi dan situasi kerja akan tetapi juga memilih, membuat, dan memengaruhi lingkungan kerja serta jalur karier mereka sehingga secara konsisten akan mengarahkan mereka kepada tingkat kesuksesan dalam berkarier yang lebih baik (Spurk, 2013).

\section{Career Adaptability}

Career adaptability merupakan kegiatan tertentu untuk mengasah serta menggunakan sumber daya psikososial yang penting untuk melakukan perubahan dalam diri dan situasi guna mencapai kepuasan dan kesuksesan karier (Maree, 2017). Career adaptability pertama kali muncul dalam tradisi perkembangan karier sebagai konstruksi untuk menafsirkan dan memajukan pengembangan karier individu dewasa dengan cara meningkatkan kematangan karier seba- 
gai konstruksi yang diterapkan pada proses pengembangan karier selama masa remaja (Savickas, 1997; Super \& Knasel, 1981). Career adaptability memiliki empat dimensi yaitu: concern, control, curiosity, dan confidence (Savcikas, 2012).

\section{PENGEMBANGAN HIPOTESIS}

H1: Proactive personality berpengaruh positif dan signifikan terhadap subjective career success

$\mathrm{H} 2$ : Proactive personality berpengaruh positif dan signifikan terhadap objective career success

H3: Proactive personality berpengaruh positif dan signifikan terhadap career adaptability

H4: Career adaptability berpengaruh positif dan signifikan terhadap subjective career success

H5: Career adaptability berpengaruh positif dan signifikan terhadap objective career success

H6: Terdapat pengaruh tidak langsung bersifat positif signifikan dari proactive personality terhadap subjective career success melalui career adaptability

H7: Terdapat pengaruh tidak langsung bersifat positif signifikan dari proactive personality terhadap objective career success melalui career adaptability

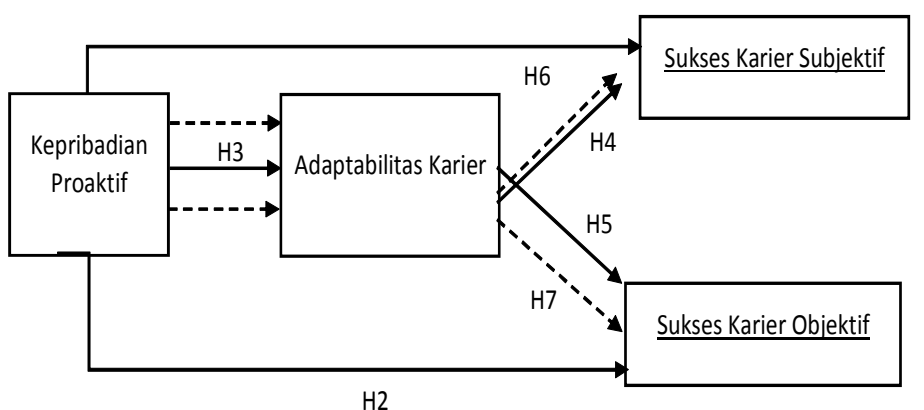

Gambar 1 Kerangka Konseptual
Keterangan:

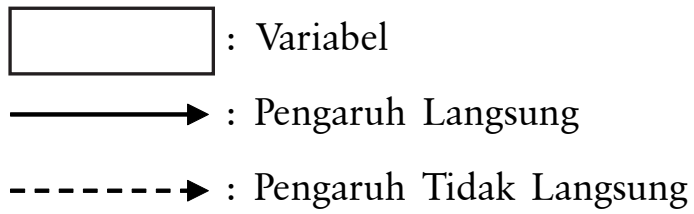

\section{METODE PENELITIAN}

Penelitian ini menggunakan pendekatan penelitian kuantitatif. Penelitian ini memiliki variabel independen dan variabel dependen. Variabel independen dari penelitian ini adalah proactive personality (X), variabel mediasi dari penelitian ini adalah adpatabilitas karier (career adaptability) (Z), sedangkan variabel dependen dari penelitian ini adalah sukses karier subjektif (subjective career success) (Y1) dan objective career success (Y2). Setiap item diukur menggunakan skala likert berjenjang 5 dengan urutan: sangat tidak setuju hingga sangat setuju

Penelitian ini dilakukan pada PT KAI Daop 8 Surabaya dengan pembagian wilayah meliput: Depo Kereta Besar A Sidotopo, Depo Lokomotif Besar A Sidotopo, Depo Gerbang Besar A Sidotopo, Stasiun Besar A Surabaya Gubeng, dan Stasiun Besar A Surabaya Pasarturi. Populasi adalah kumpulan dari individu dengan kualitas serta ciri-ciri yang telah ditetapkan (Anshori dan Iswati, 2009). Populasi dalam penelitian ini adalah seluruh karyawan PT KAI DAOP 8 Surabaya. Sampel adalah bagian dari jumlah dan karakteristik yang dimiliki oleh populasi (Anshori dan Iswati, 2009). Sampel pada penelitian ini adalah sebagian dari karyawan yang telah mengalami kenaikan jabatan setidaknya satu kali serta sampel pada penelitian ini berjumlah 41 orang responden. Pengambilan sampel dalam penelitian ini dilakukan dengan cara nonprobability sampling. Sedangkan teknik sampling yang dipilih peneliti adalah teknik purposive sampling. Pur- 
posive sampling adalah teknik penentuan sampel dengan pertimbangan tertentu (Anshori dan Iswati, 2009). Kriteria sampel pada penelitian ini adalah individu yang telah mengalami kenaikan jabatan setidaknya satu kali Stasiun Besar A Surabaya Pasarturi. Penelitian ini dilakukan pada 30 Juli 2018 sampai dengan 29 Agustus 2018.

\section{E. DEFINISI OPERASIONAL VARIABEL}

1. Proactive personality adalah mengacu pada karyawan PT KAI Daop 8 Surabaya yang memiliki sikap relatif tidak terbatasi oleh kekuatan situasional serta dapat memengaruhi perubahan lingkungannya.

2. Subjective career success didefinisikan sebagai seberapa puas karyawan PT KAI Daop 8 Surabaya terhadap pekerjaan atau karier yang mereka capai.

3. Objective career success didefinisikan sebagai prestasi karier karyawan PT KAI Daop 8 Surabaya yang dapat diamati seperti gaji dan promosi.

4. Career adaptability seperangkat sikap, perilaku, dan kompetensi yang digunakan karyawan PT KAI DAOP 8 Surabaya dalam menghadapi perubahan kondisi kerja dan tuntutan, yang terdiri dari empat dimensi: concern (perencanaan), kontrol (pengambilan keputusan, penentuan), rasa ingin tahu (mengeksplorasi), dan kepercayaan diri (pemecahan masalah, percaya diri).

\section{F. TEKNIK ANALISIS}

Penelitian ini menggunakan PLS-SEM karena metode ini dapat menjawab hipotesis penelitian dengan jumlah responden yang tergolong sedikit (Hair dkk., 2016). Hal ini sesuai dengan penelitian yang peneliti lakukan dengan jumlah responden yang kurang dari 100 tepatnya sebanyak 41 responden. Tahap pertama adalah dengan menguji kecocokan antara model dengan data. Proses ini dilakukan dengan dua macam model pengukuran, yaitu: outer model dan inner model.

\section{G. HASIL DAN PEMBAHASAN}

1. Uji Hipotesis

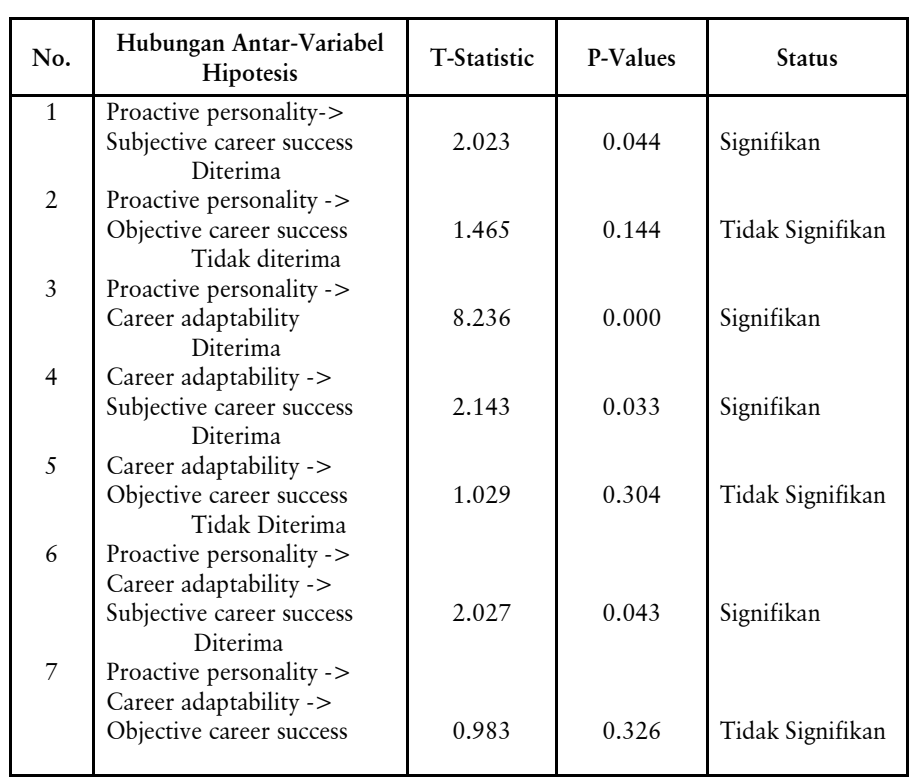

\section{Pembahasan}

Berdasarkan atas hasil output analisis uji hipotesis dengan menggunakan SmartPLS, berikut adalah pembahasan untuk masing-masing hipotesis.

1. Hipotesis 1: proactive personality berpengaruh positif terhadap subjective career success

Berdasarkan uji bootstrapping pada model menunjukkan bahwa proactive personality (X) berpengaruh positif secara signifikan terhadap subjective career success (Y1) dengan nilai tstatistik sebesar 2,023 dan tingkat signifikansi 
sebesar 0,04. Artinya, semakin tinggi tingkat proactive personality seseorang maka akan semakin tinggi subjective career success yang dialaminya. Oleh karena itu, hipotesis 1 yang menyatakan proactive personality berpengaruh positif terhadap subjective career success, diterima.

Hasil dari uji ini sesuai dengan penelitian yang dilakukan oleh Spurk (2013) bahwa proactive personality memiliki pengaruh positif terhadap subjective career success. Hasilnya menunjukkan bahwa seseorang yang bersikap lebih proaktif memiliki tingkat kesuksesan karier subjektif yang lebih tinggi juga. Menurut penelitian yang dilakukan oleh Siebert, dkk. (1999) individu yang bersikap lebih proaktif akan memiliki sense determination dan self-efficacy yang lebih tinggi terhadap pekerjaannya, yang artinya mereka akan lebih puas terhadap karier mereka.

\section{Hipotesis 2: proactive personality Berpe-} ngaruh Positif Terhadap Objective career success

Berdasarkan uji bootstrapping pada model, menunjukkan bahwa proactive personality tidak berpengaruh secara signifikan terhadap objective career success. Hal tersebut terjadi karena nilai t-statistik berada di bawah 2,02 serta nilai p-value lebih besar dari 0,05 yaitu 0,144 . Sehingga dapat dinyatakan bahwa hipotesis 2 yang menyatakan proactive personality berpengaruh positif terhadap objective career success ditolak.

Hal ini bertentangan dengan hasil penelitian yang dilakukan oleh Spurk (2013) yang menyatakan bahwa proactive personality berpengaruh positif terhadap objective career success. Hal ini dapat dipengaruhi oleh perbedaan jumlah responden dan ketersediaan waktu yang diberikan kepada responden di saat pengisian kuesioner. Hal yang dilakukan oleh Spurk (2013) dalam melakukan penelitiannya adalah membagikan kuesionernya secara online kepada 385 calon responden kemudian mereka diberi kebebasan waktu untuk mengisi kuesioner tersebut. Metode seperti ini tentu memiliki kelebihan yaitu data bisa tersebar ke banyak calon responden, akan tetapi kelemahannya adalah tidak semua responden benar-benar mengisi kuesioner dengan penuh kesadaran. Terlihat bahwa kuesioner yang kembali dari 385 hanyalah 153, kurang dari 50\% dari jumlah calon responden. Sisanya tidak dapat digunakan karena tidak semua pertanyaan dijawab oleh responden. Sehingga hal ini tentu akan berbeda dengan metode penyebaran kuesioner penelitian ini yang dilakukan pada jam kerja dan diambil pada jam kerja.

3. Hipotesis 3: proactive personality berpengaruh positif terhadap career adaptability

Berdasarkan uji bootstrapping di atas, dapat dilihat bahwa proactive personality berpengaruh positif signifikan terhadap career adaptability dengan nilai t-statistik 8,236 yang mana artinya lebih besar dari t-tabel yaitu 2,02. Selain itu nilai signifikan dari hubungan ini adalah 0,000 di mana hasil tersebut menunjukkan pengaruh yang signifikan karena berada di bawah 0,05. Sehingga dapat dinyatakan bahwa hipotesis 3 yang menyatakan bahwa proactive personality memiliki pengaruh signifikan positif terhadap career adaptability, dapat diterima.

Hasil penelitian ini sesuai dengan penelitian yang dilakukan oleh Tolentino dkk. (2013) yang menyatakan bahwa semakin tinggi tingkat proaktif seseorang maka akan semakin tinggi tingkat adaptabilitas seseorang dalam bekerja. Tolentino, dkk. (2013) juga menambahkan bahwa semakin siap individu dalam hal menyiapkan ketidakpastian maka akan semakin baik career adaptability yang mereka miliki. 
4. Hipotesis 4: Career adaptability berpengaruh positif terhadap subjective career success

Pengujian menggunakan bootstrapping menunjukkan hasil bahwa career adaptability memiliki pengaruh yang signifikan terhadap subjective career success, dengan perolehan t-statistik 2,143 dan nilai signifikansi sebesar 0,033. Artinya, pernyataan hipotesis 4 bahwa career adaptability berpengaruh positif terhadap subjective career success, dapat diterima.

Hasil ini sesuai dengan penelitian yang dilakukan oleh Zacher (2014) yang menyatakan bahwa career adaptability berpengaruh positif terhadap subjective career success terutama pada bagian kepuasan karier dan self-rated performance. Hasil ini wajar didapatkan mengingat hipotesis pertama dan ketiga juga diterima. Sikap karyawan PT KAI DAOP 8 Surabaya yang adaptif secara pengujian menunjukkan tendensi ke arah kepuasan terhadap pencapaian yang mereka raih terkait karier mereka. Menurut analisis peneliti, kenyataan bahwa sebagian besar responden adalah lulusan SMA/SMK menjadikan pekerjaan mereka dipandang sebagai sesuatu yang membanggakan bagi mereka. Terlebih perusahaan tempat mereka bekerja termasuk ke dalam Badan Usaha Milik Negara (BUMN) di mana hal-hal seperti kebanggaan dapat menjadi bagian di dalamnya merupakan hal yang lumrah terjadi.

\section{Hipotesis 5: career adaptability berpengaruh} positif terhadap objective career success

Hasil uji bootstrapping menunjukkan bahwa tidak terdapat pengaruh yang signifikan antara career adaptability terhadap objective career success, dengan detail t-statistik 1,029 dan pvalue sebesar 0,304 . Hal ini berarti pernyataan hipotesis 5 berupa career adaptability berpengaruh positif terhadap objective career success, tidak dapat diterima.
Hasil ini bertentangan dengan penelitian yang dilakukan oleh Spurk (2013) bahwa adaptabilitas karier berpengaruh signifikan positif terhadap objective career success. Perbedaan hasil ini memiliki kecenderungan akibat adanya perbedaan sistem karier di Indonesia dengan di luar negeri. Pada PT KAI Daop 8 Surabaya, jabatanjabatan tinggi masih dipegang oleh para senior yang telah lama bekerja. Berbeda halnya dengan keadaan di luar negeri yang sangat umum ditemui para pemegang jabatan tinggi berada di usia yang dapat dikatakan muda. Jika dilihat dari jawaban responden terkait objective career success, setidaknya terdapat 20 orang dari jumlah total 41 orang yang menjawab cukup puas terhadap keseluruhan promosi yang diterima. Hal ini menggambarkan bahwa untuk mendapatkan promosi di PT KAI Daop 8 Surabaya merupakan hal yang cukup sulit untuk dicapai meskipun mereka telah memiliki sikap yang adaptif.

6. Hipotesis 6: terdapat pengaruh tidak langsung bersifat positif dari proactive personality terhadap subjective career success melalui career adaptability

Berdasarkan uji bootstrapping terdapat pengaruh tidak langsung yang bersifat positif antara proactive personality terhadap subjective career success melalui career adaptability. Lebih detailnya adalah nilai t-statistik 2,027 dan nilai signifikansi sebesar 0,043. Artinya, hipotesis 6 yang menyatakan adanya pengaruh tidak langsung bersifat positif antara proactive personality terhadap subjective career success melalui career adaptability, dapat diterima.

Berdasarkan penelitian yang dilakukan oleh Spurk (2013) bahwa individu dengan proactive personality lebih adaptif terhadap karier mereka serta mereka akan lebih puas terhadap pekerjaan mereka dan karier mereka sesuai dengan hasil 
dari penelitian ini yang dinyatakan lewat hipotesis 6. Spurk (2013) juga menyatakan bahwa individu dengan proactive personality dan adaptif terhadap karier mereka akan merasa diri mereka lebih dihargai baik dari sisi perusahaan tempat ia bekerja maupun di pasar tenaga kerja.

7. Hipotesis 7: terdapat pengaruh tidak langsung bersifat positif dari proactive personality terhadap objective career success melalui career adaptability

Uji bootstrapping yang dilakukan menunjukkan bahwa tidak terdapat pengaruh tidak langsung yang signifikan antara proactive personality terhadap objective career success melalui career adaptability. Dapat dilihat bahwa nilai tstatistik yaitu 0,983 dan signifikansi 0,326. Sehingga pernyataan hipotesis 7 bahwa terdapat pengaruh tidak langsung bersifat positif dari proactive personality terhadap objective career success melalui career adaptability, ditolak.

Hasil ini tidak sesuai dengan hasil penelitian yang dilakukan oleh Spurk (2013) bahwa career adaptability dapat menjelaskan hubungan proactive personality terhadap objective career success, artinya bahwa terdapat pengaruh signifikan positif antara proactive personality terhadap $o b$ jective career success melalui career adaptability. Akan tetapi, hasil penelitian ini mendukung penelitian dari Seibert (2001) bahwa tidak terdapat pengaruh signifikan antara proactive personality dengan objective career success.

\section{H. SIMPULAN}

Berdasarkan uraian-uraian di atas serta hasil penelitian yang telah dilakukan terhadap dapat ditarik kesimpulan sebagai berikut.

1. Proactive personality memiliki pengaruh signifikan positif terhadap subjective career suc- cess, serta terdapat pengaruh tidak langsung antara proactive personality terhadap subjective career success melalui career adaptability. Artinya, semakin tinggi tingkat proactive personality karyawan maka akan semakin tinggi pula kepuasan yang mereka peroleh terkait kemajuan mereka dalam berkarier.

2. Terdapat beberapa ketidaksesuaian antara hasil penelitian dengan hasil penelitian terdahulu yaitu bahwa tidak terdapat pengaruh yang signifikan antara proactive personality terhadap objective career success maupun tidak terdapat pengaruh yang signifikan antara proactive personality terhadap objective career success melalui career adaptability. Perbedaan ini disebabkan karena kondisi karier di Indonesia umumnya mengaitkan keputusan posisi jabatan dengan status lama bekerja karyawan tersebut, serta terdapat faktor-faktor lain di luar penelitian yang dapat dimasukkan ke dalam penelitian. Sehingga konsep proactive personality memengaruhi objective career success memiliki keterbatasan tertentu jika diterapkan di Indonesia.

\section{SARAN}

Hasil pengujian dan analisis yang dilakukan menunjukkan bahwa sikap proactive personality dan bentuk adaptif dalam berkarier merupakan hal yang perlu diperhatikan dalam menjalankan pekerjaan. Selain berguna untuk mencapai kepuasan dalam berkarier, hal ini juga dapat mendorong tumbuhnya lingkungan kompetitif yang sehat dalam perusahaan yang tentunya diharapkan berdampak positif bagi perkembangan perusahaan. Sehingga patut untuk dipertimbangkan bahwa merupakan hal yang lumrah ketika individu/karyawan dengan usia muda dapat mendu- 
duki jabatan yang tinggi. Selain menciptakan kondisi kompetitif dalam lingkungan kerja, hal ini juga dapat menjaga kinerja dari seluruh karyawan baik yang muda maupun senior karena mereka mengetahui kenyataan bahwa siapa pun memiliki kesempatan yang sama untuk dapat meraih posisi jabatan yang lebih tinggi dari pada yang mereka rasakan sekarang.

Saran untuk penelitian selanjutnya adalah memperbanyak jumlah responden penelitian agar diharapkan hasil yang diperoleh bisa lebih akurat dan menggambarkan keadaan yang sebenarnya. Di samping itu, diharapkan pada penelitian berikutnya akan dimasukkan faktor-faktor lain yang ada di luar penelitian ini agar memberikan ragam hasil yang lebih luas dan dapat merepresentasikan keadaan yang sebenarnya terjadi di lapangan. Menurut analisis dari penulis, variabel-variabel seperti manajemen karier, motivasi, dan selfefficacy patut untuk dipertimbangkan untuk penelitian selanjutnya.

\section{J. DAFTAR RUJUKAN}

Anshori, H.M. \& Iswati, H.S. 2009. Buku Ajar Metodologi Penelitian Kuantitatif. Surabaya: Pusat Penerbitan dan Percetakan Unair (AUP).

Arthur, M.B., Khapova, S.N., \& Wilderom, C.P. 2005. Career Success in a Boundaryless Career World. J. Organiz. Behav. 26, 177202 (2005).

Bakker, A.B., Tims, M., \& Derks, D. 2012. Proactive Personality and Job Performance: The Role of Job Crafting and Work Engagement. Human Relations, 65, 13591378.

Bateman, T.S. \& Crant, J.M. 1993. The proactive component of organizational behavior: A measure and correlates. Journal of
Organizational Behavior, Vol. 14,103-118 (1993).

Bateman, T. \& Crant, J.M. 1999. Proactive Behavior: Meaning, Impact, Recommendations. Business Horizons, May/Jun99, Vol. 42 Issue 3, p63, 8p, 1 bw.

Bateman, T. \& Michael, C.J. 1999. Proactive Behavior: Meaning, Impact, Recommendations. Source. Business Horizons, May/ Jun99, Vol. 42 Issue 3, p63, 8p, 1 bw.

Boateng, F. G. 2016. Knowledge Sharing among Teachers: The Role of the Big Five Personality Traits. VINE Journal of Information and Knowledge Management Systems, Vol. 46 Iss 1.

Bocciardi, F., Caputo, A., Fregonese, C., Langher, V., \& Sartori, R. 2017. Career Adaptability as a Strategic Competence for Career Development an Exploratory Study of Its Key Predictors. European Journal of Training and Development, Vol. 41 Iss 1 pp. 67-82.

Bozionelos, N. 2004. The Big Five of Personality and Work Involvement. Journal of Managerial.

Buss, D.M. 1983. The Act Frequency Approach to Personality. Psychological Review, 90, 105-126.

Cochran, L. 1994. What Is a Career Problem? The Career Development Quarterly, March 1994, Vol. 42.

Crant, J. 2000. Proactive Behavior in Organizations. Journal of Management, Vol. 26 No. 3, 435-462.

Denollet, J. 1998. Personality and Coronary Heart Disease: The Type-D Scale-16 (DS16). Annals of Behavioral Medicine, 1998, Vol. 20, 209-215.

Dotlich, D.P.C. \& Rhinesmith, S. 2008. Complexity, Diversity, and Uncertainty - the 
Shaky New Ground for CEOs. People \& Strategy, Vol. 31, No. 2, 44-51.

Dougherty, T.W., Cheung, Y.H., \& Florea, L. 2008. The Role of Personality in Employee Developmental Networks. Journal of Managerial Psychology, 653-669.

Dreher, G.A. 1990. A Comparative Study of Mentoring among Men and Women in Managerial, Professional, and Technical Positions. Journal of Applied Psychology, Vol. 75, 539-546.

Drost, J.W. 2016. Core Personality Traits of Managers. Journal of Managerial Psychology, Vol. 31 Iss 2.

DuBrin, A.J. 2013. Proactive Personality and Behavior for Individual and Organizational Productivity. Edward Elgar Publishing.

Epstein, S. 1979. The Stability of Behavior: I. On Predicting Most of the People Much of the Time. Journal of Personality and Social Psychology, 37, 1097-1126.

Gattiker, U. \& Larwood, L. 1988. Predictors for Managers' Career Mobility, Success, and Satisfaction. Human Relations, Vol. 41 No. 8, 569-91.

Greenhaus, J., Parasuraman, S., \& Wormley. 1990. Effects of Race on Organizational Experiences, Job Performance Evaluations and Career Outcomes. Academy of Management Journal, Vol. 33 No. 1, 64-86.

Hair Jr., J.F., Black, W.C., Babin, B.J., \& Anderson, R.E. 2014. Multivariate Data Analysis (7th ed). s.1.: Pearson Prentice-Hall.

Heneman, H. \& Schwab, D. 1985. Pay Satisfaction: Its Multidimensional Nature and Measurement. International Journal of Psychology, Vol. 20, 129-141.

Henseler, J., Ringle, C.M., \& Sinkovics, R.R. 2009. The Use of Partial Least Squares Path Modeling in International Marketing. International Marketing, 20, 277-319.
Hirschi, A.H. 2014. Career Adaptivity, Adaptability, and Adapting: a Conceptual and Empirical Investigation. Journal of Vocational Behaviour, Vol. 87, 1-10.

https://www.kai.id/. 2018. Retrieved from https:/ /www.kai.id/corporate/about_kai/.

Jaya, I.G. \& Sumertajaya, I.M. 2008. Pemodelan Persamaan Struktural dengan Partial Least Square. Semnas Matematika dan Pendidikan Matematika, 1-118.

Jeffrey H. Greenhaus, G.A. 2010. Career Management. SAGE.

Jiang, Z. 2016. Proactive Personality and Career Adaptability: The Role of Thriving at Work. Journal of Vocational Behavior.

Jones, B. 2012. Innovation and Human Resources: Migration Policies and Employment Protection Policies. Manchester Institute of Innovation.

King, Z. 2004. Career Self-Management: Its Nature, Causes, and Consequences. Journal of Vocational Behavior, Vol. 65.

Koen, J., Klehe, U.-C., Vianen, A.E., Zikic, J., \& Nauta, A. 2010. Job-Search Strategies and Reemployment Quality the Impact of Career Adaptability. Journal of Vocational Behavior vol. 77, 126-139.

Langelaan, S., Bakker, A.B., van Doornen, L.J., \& Schaufeli, W.B. 2006. Burnout and Work Engagement: Do Individual Differences Make a Difference? Personality and Individual Differences, 521-532.

Larsen, R.J. 2005. Personality Psychology. Domains of Knowledge about Human $\mathrm{Na}$ ture (2nd Ed.). New York: McGraw Hill. Lau, V.P., \& Shaffer, M.A. 1999. Career Success. The Effects of Personality. Career Development International, Vol.4 Iss 4, 225-231.

Maree, K. 2017. Psychology of Career Adaptability, Employability, and Resilience. Psy- 
chology of Career Adaptability, Employability and Resilience, 1-453.

Mayer, J.D. 2007. Asserting the Definition of Personality. The Online Newsletter for Personality Science Issue 1, Spring 2007, 342-343.

Nawawi, H. 1993. Dasar-Dasar Manajemen dan Manajemen Gerakan Pramuka. Yogyakarta: Gadjah Mada University Press. Prabhu, V.P., McGuire, S.J., Drost, E.A., \& Kwong, K.K. 2012. Proactive Personality and Entrepreneurial Intent: Is Entrepreneurial Self-Efficacy a Mediator or Moderator? International Journal of Entrepreneurial Behaviour and Research 18, 559586.

Prasojo, L.D., Mukminin, A., \& Mahmudah, F.N. 2018. Manajemen Strategi Human Capital dalam Pendidikan. Yogyakarta: UNY Press.

Rasdi, R.I. 2011. Predicting Malaysian Managers Objective and Subjective Career Success. International Journal of Human Resource Management, Vol. 22 No. 17, pp. 3528-3549, 3528-3549.

Robbins, S.P. 2001. Organizational Behavior 9th. International, Prentice Hall.

Robbins, S.T., Judge, T.A., \& Hasham, E.S. 2012. Organizational Behavior.

Rottinghaus, P.J., Day, S.X., \& Borgen, F.H. 2005. The Career Futures Inventory: A Measure of Career-Related Adaptability and Optimism. Journal of Career Assessment, Vol. 13 No. 1, 3-24.

Ryckman, R.M. 2012. Theories of Personality. Cengage Learning.

Santos, G.G. 2016. Career Barriers Influencing Career Success a Focus on Academics' Perceptions and Experiences. Career Development, Vol. 21 Iss 1 pp. 60-84.
Savickas, M.A. 2012. "Career Adapt-Abilities Scale: Construction, Reliability, and Measurement Equivalence across 13 Countries. Journal of Vocational Behavior, Vol. 80 No. 3, pp. 2661-2673, doi: 10.1016/ j.jvb.2012.01.011.

Savickas, M.L. 1997. Career Adaptability: An Integrative Construct for Life-Span, LifeSpace Theory. The Career Development Quarterly, March 1997, Vol. 45, 247259.

Savickas, M.L. 2002. Career Construction: A Developmental Theory of Vocational Behavior. In D. Brown \& Associates (Eds.). Career Choice and Development 4th ed, 149-205.

Savickas, M.L. 2005. The Theory and Practice of Career Construction. In S.D. Brown \& R.W. Lent (Eds). Career Development and Counseling: Putting Theory and Research To Work, 42-70.

Savickas, M.L. \& Porfeli, E.J. 2012. Career Adapt-Abilities Scale: Construction, Reliability, and Measurement Equivalence across 13 Countries. Journal of Vocational Behavior 80(3), 661-673.

Scarpello, V., Scarpello, V., \& Campbell, J. 1983. Job Satisfaction: Are All the Parts There? Personnel Psychology, Vol. 36, 577600.

Scott, S.G. 1994. Determinants of Innovative Work Behavior: A Path Model of Individual Innovation in The Workplace. Academy of Management Journal, 38, 14421165.

Seibert, E.S. \& Maria, L.K. 2001. The FiveFactor Model of Personality and Career Success. Journal of Vocational Behavior, Vol. 58 . 
Seibert, S., Crant, J.M., \& Kraimer, M.L. 1999. Research Report "Proactive Personality and Career Success". Journal of Applied Psychology.

Spurk, D., Kauffeld, S., Barthauer, L., \& Heinemann, N.S. 2015. Fostering Networking Behavior, Career Planning and Optimism, and Subjective Career Success: An Intervention Study. Journal of Vocational Behavior 87, 134-144.

Spurk, D., Volmer, J., Hagmaier, T., \& Kauffeld, S. 2013. Why are Proactive People More Successful in Their Careers? The Role of Career Adaptability in Explaining Multiple Career Success Criteria. E.E. Crossman, \& M.A. Weiler (eds.), Personality Traits: Causes, Conceptions and Consequences. New York: Nova Publishers.

Super, D.E. 1974. Measuring vocational maturity for counseling and evaluation. Washington, DC. National Vocational Guidance Association.

Super, D.E. 1981. Career Development in Adulthood: Some Theoretical Problems and a
Possible Solution. British journal o/Guidance and Counseling, 9,194-201.

Tolentino R.L.M.P.R., NhatLu, G., D. Restubog, S.L., PrashantBordia, \& CarolinPlewa. 2013. Career Adaptation: The Relation of Adaptability to Goal Orientation, Proactive Personality, and Career Optimism. Journal of Vocational Behavior, Vol. 84.

Yang, F., \& Chau, R. (467-482). Proactive Personality and Career Success. Journal of Managerial Psychology, Vol. 31 Iss 2.

Zacher, H. 2014. Career Adaptability Predicts Subjective Career Success Above and Beyond Personality Traits and Core SelfEvaluations. Journal of Vocational Behavior, Vol. 84, 21-30.

Zhu, G., Wolff, S.B., Hall, D.T., Heras, M.L., Gutierrez, B., \& Kram, K. 2013. Too Much or Too Little? A Study of the Impact of Career Complexity on Executive Adaptability. Career Development International, Vol. 18 Iss 5 pp. 457-483. 